\title{
HYDROGEOCHEMICAL APPRAISAL OF FLUORIDE IN GROUNDWATER OF LANGTANG AREA, PLATEAU STATE, NIGERIA
}

\author{
H. U. DIBAL, K. SCHOENEICH, U. A. LAR, I. GARBA, I. C. LEKMANG AND R. I. DASPAN
}

(Received 5 June 2015; Revision Accepted 17 August 2015)

\begin{abstract}
Consumption of high fluoride in groundwater of Langtang area, manifest in the inhabitants of the area in form of dental fluorosis and skeletal fluorosis in older group. The aim of this study was to appraise the hydrogeochemistry of fluoride in the groundwaters of Langtang area. Thirty seven surface and groundwater samples and nine rock samples were collected in Langtang area for geochemical analysis. The Inductively Coupled Plasma Emission Spectrometry (ICPOES) was used to detect cations. The anions $\left(\mathrm{Cl}^{-}, \mathrm{SO}_{4}{ }^{\circ}\right.$ and $\left.\mathrm{Br}^{-}\right)$were determine by lon Chromatography method. Fluoride was determined by the Specific Ion Electrode and bicarbonate was determined by titration. Major oxides, trace elements and rare earth elements for the rock samples were determined by the XRF method and fluorine by the Fusion method. Polished thin sections for rocks were prepared and studied. Geochemical results from analysis of the samples (rock and water) show that four major rock units make up the geology of the area; coarse porphyritic biotite granite, migmatite, rhyolite and riebeckite granites, the minor ones are pegmatite, trachyte, aplite and fine to medium grained biotite granites. The rhyolite, the riebeckite granites and trachyte have the highest level of fluorine content in the area $(1,470,1000,900$ and $800 \mathrm{ppm})$ respectively. The fluorine mineral (Fluorite) crystallized in the late stage of the magma as replacement of $\mathrm{Fe} / \mathrm{Mg}$ mineral probably hornblende or biotite. Fluorine is leached into the groundwater from the rhyolite under the slightly alkaline $\left(\mathrm{Ca}-\mathrm{Mg}-\mathrm{HCO}_{3}\right.$ evolving $\left.\mathrm{Na}-\mathrm{HCO}_{3}\right)$ water in the area. The two major groundwater types $\left(\mathrm{Ca}-\mathrm{Mg}-\mathrm{HCO}_{3}\right.$ and $\left.\mathrm{Na}-\mathrm{HCO}_{3}\right)$ in the area have good relationship with content of fluoride in water. Although, the riebeckite granites have high fluorine content, contribution of fluoride from them is towards the southern portion of the map, owing to the groundwater flow direction. The different water sources in the area do not show variation in content of fluoride in water. However, groundwater barriers (dykes) may be responsible for some area having low fluoride $(<1.5 \mathrm{mg} / \mathrm{l})$ content. The consumption of high content of fluoride in the area has resulted in severe dental fluorosis in both children and youths and bowing of legs (Genu Valgum) in children with no discrimination between the sexes.
\end{abstract}

KEYWORDS: Fluoride, Fluorite, Fluorine, Fluorosis, Riebeckite Granite, Groundwater

\section{INTRODUCTION}

In most rural communities in northern Nigeria, the supply of water for drinking and other purposes is solely from surface (ponds, streams and rivers) and groundwater. Very often the qualities of such waters destined for human consumption are not known. Fluoride levels in water is of concern because of it harmful effect to man. Fluoride levels of $<1.5 \mathrm{mg} / \mathrm{l}$ in water may cause dental carries and higher values of $>$ $1.5 \mathrm{mg} / \mathrm{l}$ fluoride content may results in the development of dental fluorosis and values of $4 \mathrm{mg} / \mathrm{l}$ may cause skeletal fluorosis (WHO, 2004). Other harmful effects associated with fluoride in drinking water are: reduced $I Q$, neurological disorder, hip fracture in women, endocrine effect (Dissanayake, 1991). Fluoride enters the human body mainly through drinking water (Dissanayake, 1991). Other sources may be from certain foods, dust, and industrial exposure. Sources of fluoride in ground water are fluoride bearing minerals from rocks, such as fluorite, Fluor-apatite, cryolite, hydroxylapatite, biotite, hornblende among others. Concentrations of fluoride are generally localized in their geological occurrence. Highest concentrations are found in acid igneous rocks, mineralized veins and sedimentary formations where biogeochemical reactions have taken place (Smedley et al, 2004). On weathering fluorine tends to be released preferentially from minerals. Where biotite and amphiboles are abundant as in granites major sources of fluoride in water bodies is formed. In sedimentary rocks apatite may be an accessory mineral contributing fluoride to water while fluorite may be cementing materials in sandstones. Consumption of fluoride in groundwater commonly manifest in the inhabitants of Langtaang area as dental caries and genu valgum (Dibal et al, 2008, Wongdem et al, 2002). The aim of this work is to geochemically appraise fluoride in the groundwater of Langtang area,

H. U. Dlbal, Department of Geology, University of Jos, Jos, Nigeria.

K. Schoeneich, Department of Geology, Ahmadu Bello University Zaria, Zaria, Nigeria.

U. A. Lar, Department of Geology, University of Jos, Jos, Nigeria.

I. Garba, Department of Geology, Ahmadu Bello University Zaria, Zaria, Nigeria.

I. C. Lekmang, Department of Geology, University of Jos, Jos, Nigeria.

R. I. Daspan, Department of Geology, University of Jos, Jos, Nigeria. 
Plateau State Nigeria with a view to understanding its sources and mobility pathways in water.

\section{DESCRIPTION OF THE STUDY AREA}

The study area is defined by latitudes $9^{\circ} 00^{\prime \prime}$ and $9^{\circ} 11^{\prime \prime} \mathrm{N}$ and longitudes $9^{\circ} 45^{\prime \prime}$ and $9^{\circ} 54^{\prime \prime}$ (Fig 1). It is part of the Crystalline Hydrogeological Province of Nigeria. Over $60 \%$ of the area is entirely underlain by coarse to porphyritic granite intruded by rhyolites on the western part, fine grained biotite granites and intrusions of aplitic , pegmatitic and microgranites with xenoliths of the coarse to porphyritic granite are common so are small volcanic hills (trachytes). Apart from the large body of the rhyolite on the western portion of the mapped area, several minor flows of the rhyolite occur as boulder on the porphyritic biotite granite and the migmatite are common within fractures of these rocks. The southern portion of the map is underlain by migmatites with large intrusion of non orogenic granite, which probably belong to the Younger Granite series of the Benue Trough of Nigeria. Pegmatite dykes have also intruded the migmatite. Large scale fault was formed as a result of the rhyolite intrusion trending in an almost $\mathrm{N}-\mathrm{S}$ direction. The study area is drained by the River Bapkwai which takes its source from the hills on the western side and flow towards the south east direction. Several other small streams which flow in the same direction drain the area.

Hydrogeologically, groundwater is found in three different aquifers; recently deposited alluvium found along river and stream channels (Soft Overburden Aquifer), Weathered Overburden and Fractured Crystalline Aquifer. Groundwater is encountered in the alluvium at depths of between $4-5 \mathrm{~m}, 10-15 \mathrm{~m}$ in the Weathered Overburden Aquifer and between $30-35 \mathrm{~m}$ in the Fractured Crystalline Aquifer. In the dry season, most of the hand dug wells dry up and water is obtained from scooped water holes in streams and river sands. 


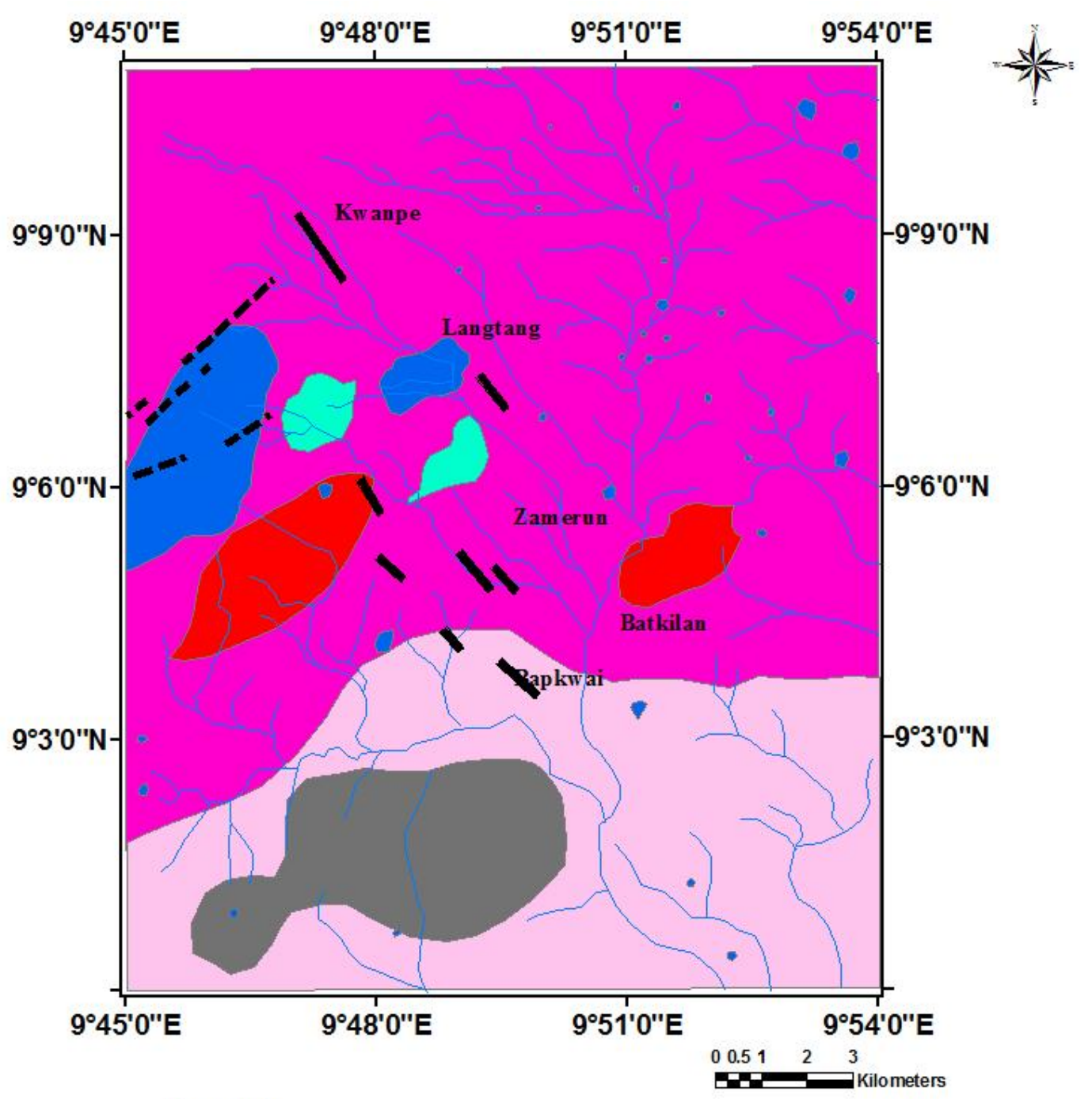

\begin{tabular}{|l|} 
Legend \\
\hline Rhyolite \\
Trachyte \\
Fine grained biotite granite \\
Riebeckite granite \\
Coarse-porphyritic biotite granite \\
Migmatite \\
Pegmatite \\
River \\
- , fault zones
\end{tabular}

Figure 1: Geological Mp of Langtang

\section{METHODOLOGY}

Water samples were collected to determine their fluoride contents and other parameters in hand dug wells, boreholes, streams, dam, springs and a pond. Hydrogen exponent and temperature were determined in the field with an Oakton $\mathrm{pH} / \mathrm{Temp} / \mathrm{meter}$. Geological mapping of the area was carried out on a scale of 1 : 20,000. Also, during the mapping exercise, rock samples were collected at several points from different rock units (trachyte, rhyolite, ribeckite granites, porphyritic biotite granite, migmatite, aplite and fine to medim grained biotite granite and pegmatite) out of which representative samples were selected for thin sectioning and pulverization. On returning from the field, the water samples were filtered with United Nation International Children Educational Fund (UNICEF) standard filter to free the water from suspended particles. The water samples were transferred into $30 \mathrm{ml}$ plastic bottles and transported to ACME Laboratory in Canada for geochemical analysis of the anions 
LABORATORY ANALYSES OF WATER AND ROCK SAMPLES

Analysis of water samples for major (cations and anions) and trace elements was carried out in two laboratories Acme Laboratory in Canada and the Department of Geology, University of Jos Laboratory). At the Activation Laboratory, the lon Chromatography was used to determine the anions, fluoride by Specific Ion Electrode and bicarbonate alkalinity was determined using titration method. At the Department of Geology University of Jos, the Inductively Coupled Plasma Optical Emission Spectrometry was used to determine the major and some trace elements. The rocks were crushed and pulverized at the Department of Geology, Ahmadu Bello University Zaria by Tungsten Carbide Ring Mill. The major oxide and elemental composition of these rocks were analysed by the XRF and the Inductively Coupled Plasma Mass Spectrometry Method at the ACME Laboratory in Canada. Fluorine in rocks were analysed by the fusion method. Three of the rock types (rhyolite and riebeckite granites) identified with high fluorine content were subjected to mineral analysis for the identification of fluorine mineral at the ACME Laboratory.

\section{EQUILIBRIUM MODELING}

Equilibrium modeling is a critical step in establishing the identity of chemical species likely to be present under given conditions particularly in aquatic system or in solutions. Numerous computer software programs are in used today to facilitate such modeling among which are MINTEQA2 (USEPA) PHREEQC (Parkhaust and Apello, 1999), The Geochemist's Workbench (Berthke, 2002) and WATEQ4F (Ball and Nordstrum, 2004).

Equilibrium modeling generally assumes that all reactions in a system have gone to completion and is thus not suited to evaluating kinetics. However, it can be very powerful in modeling equilibrium among dissolved adsorbed, solid and gas phases as a function of $\mathrm{pH}$ and ionic strength for many ionic species. Speciation refers to aspect of the chemical and physical form of an element: oxidation state, stoichemetry coordination (including the number of ligand) and physical state or association with other phases (Richard et al, 2006). These properties govern the chemical behavior of elements, whether in the environmental settings or in human organ. The potential for dissolution or precipitation of a specific mineral in aqueous solution depends on the mineral's solubility and the composition of the aqueous solution (Burt, 1993) the potential is measured by the saturation index (SI) defined by (Langmuir, 1971) as

$$
\mathrm{SI}=\log (\mathrm{IAP} / \mathrm{KT}
$$

Or by the saturation percentage (SP)

$$
\mathrm{SP}=(\mathrm{IAP} / \mathrm{KT}) \times 100
$$

Where IAP is the ion activity product in the aqueous solution of a given mineral and $\mathrm{KT}$ is the equilibrium constant at a given temperature. A value of zero (0) for the saturation index or (100 for the saturation percentage) indicate that an aqueous solution is in equilibrium with respect to the mineral. A negative value for SI or SP less than 100 indicates sub - saturation of the solution with respect to the mineral so that dissolution of the mineral is thermodynamically favoured. A positive value for SI or SP greater than 100 indicate super saturation of the solution with respect to the mineral indicating thermodynamically favoured condition for precipitation of the mineral. The ion activity products of the dissolved species are approximate due to thermodynamic uncertainties, for this reason saturation is assumed in the range $0 \pm 0.5$.

\section{RESULTS AND DISCUSSION}

\section{Petrography}

Modal mineralogy from polished thin section of the rhyolite (Plate DH1) show that K-feldspar constitute $40 \%$, occurring mainly as primary clasts and as matrix, quartz constitute $40 \%$ sericite $-5-7 \%$, plagioclase $5 \%$, chlorite $-5 \%$, fluorite - 1 , carbonate (dolomite) - 1 , rutile - 1 and pyrite $-<1$. Accessory rutile and local pyrite is concentrated in certain mafic/felsic lithic clasts respectively. Minor fluorite appears to be associated with thin carbonate veinlets. Fluorite is locally present as subhedra $<1 \mathrm{~mm}$. Generally this sample consists of about $30-40 \%$ recognizable felsic lithic clasts and 25 $30 \%$ quartz/feldspar and sparse relict (chloritized) mafic crystal shards set in a finely comminuted matrix of $\mathrm{K}$ felspar-quartz sericite (Plate DH1). 


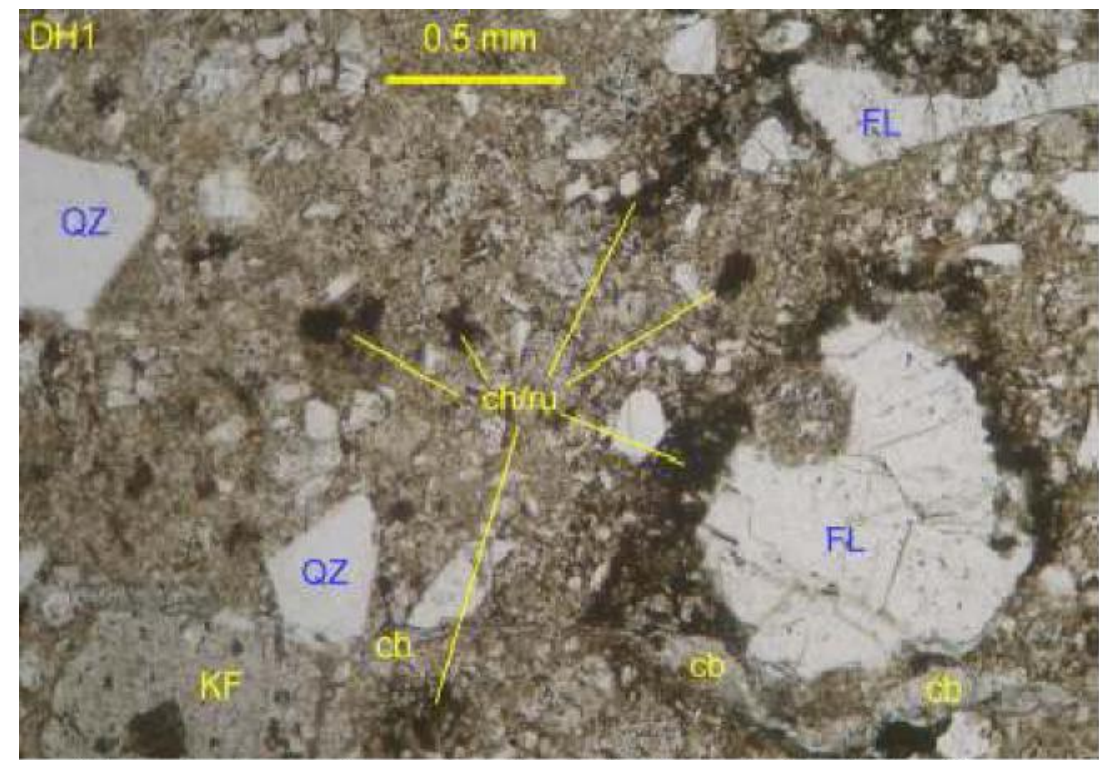

Plate 1: Fluorite (FI) possibly replacing mafic crystal shards (note dark rim of chlorite-accessory rutile), associated with thin carbonate $(\mathrm{cb})$ veinlets, cutting rhyolitic tuff containing shards of quartz (qz) and kspar (kf) in fine-grained matrix of k-felhspar-quartz-minor sericite. Transmitted plane light, field of view $\sim 3 \mathrm{~mm}$ wide.

Modal mineralogy in polished thin section of the riebeckite granite (Plate 2, HDX1) is approximately: Kfeldspar (mainly primary) 60\%, Quartz (mainly primary) $30 \%$, Biotite (partly chloritized) $3 \%$, Hematite 2\%, Sericite, clay $2 \%$, Plagioclase $1 \%$, Rutile, sphene (associated with relict mafic sites) $\sim 1 \%$, Sodic amphibole (dark blue, riebeckite?) $<1 \%$, Fluorite (associated with relict mafic sites) $<1 \%$, Apatite (associated with relict mafic sites) $<1 \%$, Zircon/monazite, associated with mafic sites $<1 \%$, Carbonate (inclusions in fluorite; possibly dolomite) $<<1 \%$. Traces of carbonate $<35 \mu \mathrm{m}$ in size may be included in the fluorite.

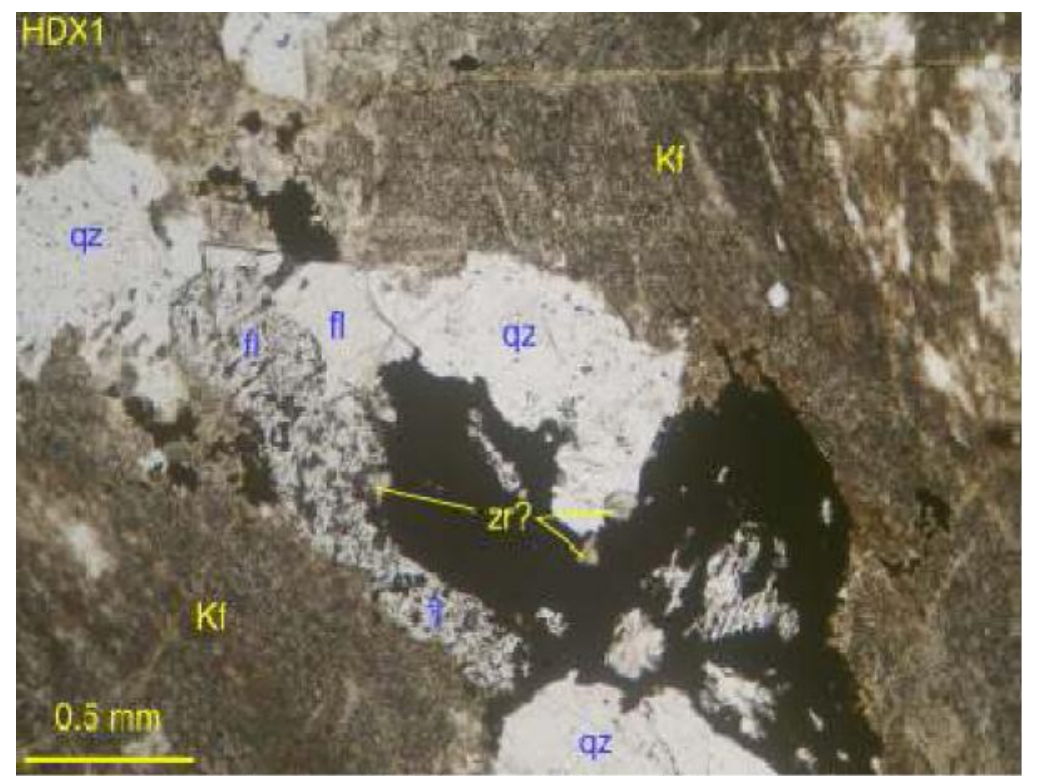

Plate 2: Riebeckite granite composed of coarse k-feldspar (kf, perthitic orthoclase) with interstitial quartz (qz), relict mafic site replaced by fluorite (fl, either clear or clouded by minute inclusions of carbonate) Transmitted plane light, field of view $\sim 3 \mathrm{~mm}$ wide.

The riebeckite granite (Plate 3, HDX2) modal mineralogy in polished thin section is approximately: Kfeldspar (mainly primary) 50\%, Quartz (primary phenocrysts/groundmass, partly micrographic) - 30\%, Plagioclase - $10 \%$, Sodic amphibole (dark blue-green, riebeckite) - 5\% Hematite (after magnetite, some of which remains)- $2 \%$ Sericite, clay (after mafics, feldspars) - 1\%, Rutile, sphene (associated with relict mafic sites) $\sim 1 \%$ Limonite (goethite/hematite, after magnetite/hematite) $\sim 1 \%$ and Apatite trace. (Plate 2 ). 


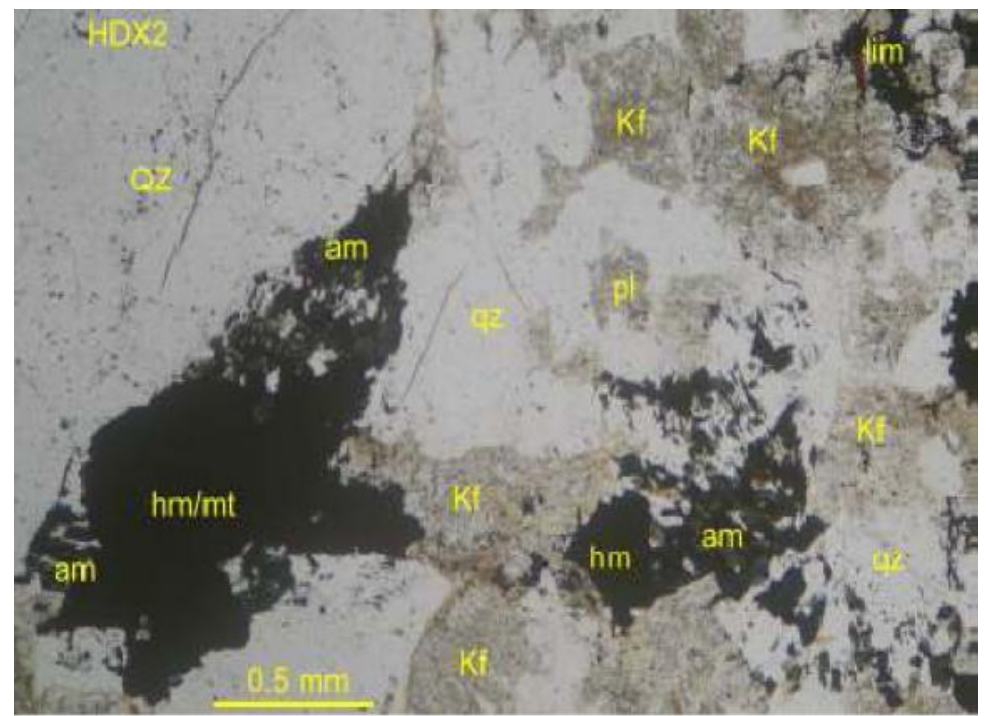

Plate 3: Margin of Quartz Phenocryst (Qz), Relict Mafic Crystals set in Phaneritic Groundmass of Quartz (Qz) and KFeldspar (Kf) with local minor Plagioclase (overgrown by Quartz) in Granite/Rhyolite Porphyry). Transmitted Plane Light, Field of View $\sim 3 \mathrm{~mm}$ wide.

No fluorite was observed in this section, but the presence of possible $\mathrm{Fe}-\mathrm{Na}$ rich amphibole which is associated with fluorite in the previous sample, suggests it could be present in the sample.

\section{Whole Rock Geochemistry}

The bulk XRF analysis of rocks in the study area (oxide composition) is presented in Table 1. Plutonic rocks diagram classification of $\mathrm{Na}_{2} \mathrm{O}+\mathrm{K}_{2} \mathrm{O}$ versus $\mathrm{SiO}_{2}$ according to Middlemost 1996 is presented in (Fig 2). The TAS classification diagram for the volcanic rocks (Middlemost, 1994) is presented (Fig 3).

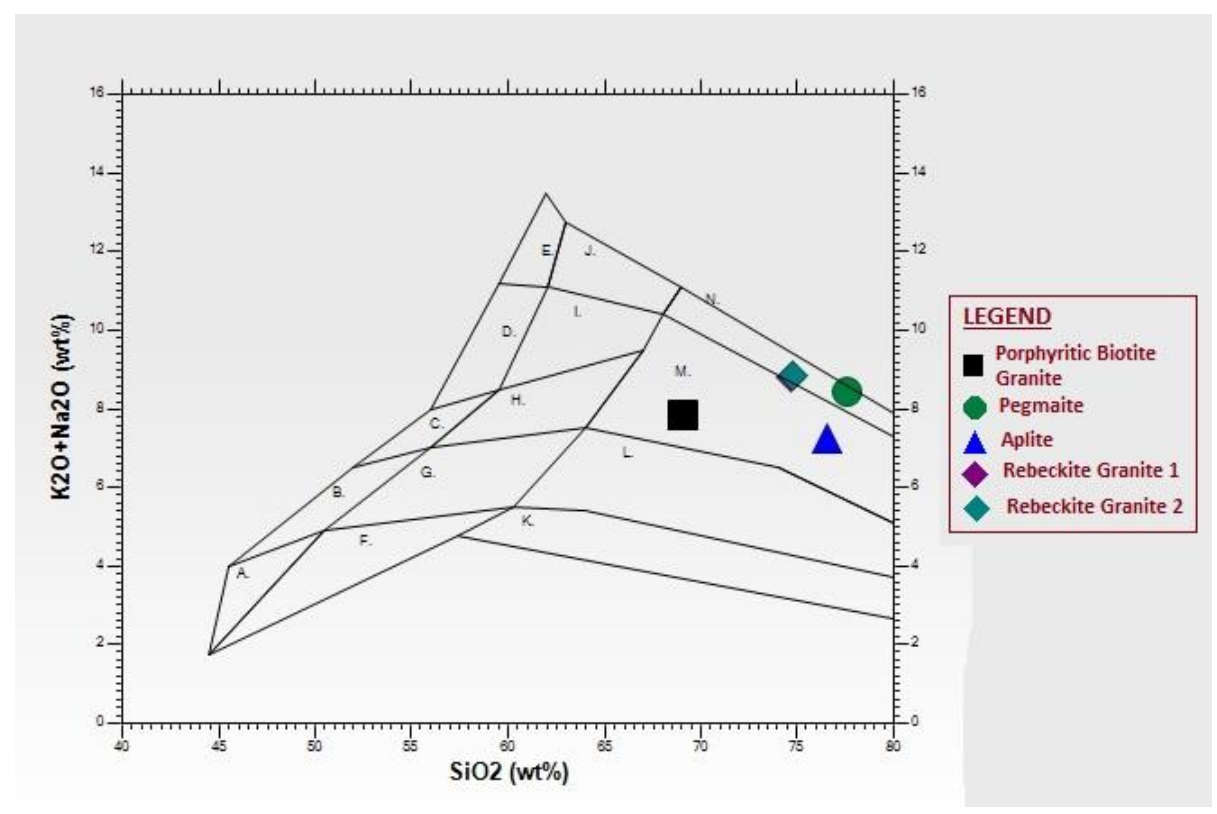

\begin{tabular}{|c|}
\hline A. Diorite, Gabbro \\
B. Monzodiorite \\
C. Monzonite \\
D. Syenite \\
E. Alkali Feldspar \\
Syenite \\
F. Quartz Diorite \\
G. Quartz \\
Monzodiorite \\
H. Quartz Monzonite \\
I. Quartz Syenite \\
J. Alkali Felds. Qtz. \\
Syenite \\
K. Tonalite \\
L. Granodiorite \\
M. Granite \\
N. Alkali Feldspar \\
Granite \\
\end{tabular}

Figure 2: TAS discrimination diagram for plutonic rocks (Middlemost, 1996) 


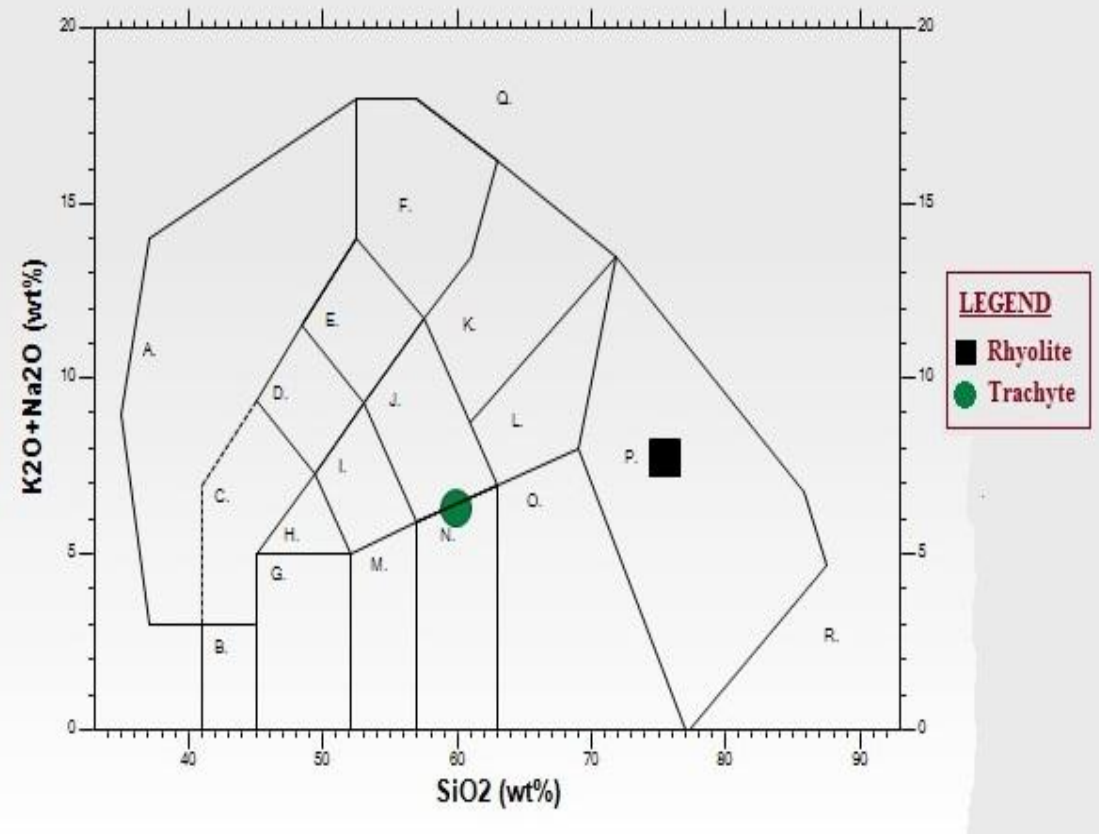

Classification

Legend for TAS-

Middlemost, 1994

A. Foidite

B. Picrobasalt

C. Basanite (Olivine $>10 \%)$

C. Tephrite (Olivine $<10 \%$

D. Phonotephrite

E. Tephriphonolite

F. Phonolite

G. Basalt

H. Trachybasalt

I. Basaltic

Trachyandesite

J. Trachyandesite

K. Trachyte (Quartz $<20 \%$ )

L. Trachydacite

M. Basaltic Andesite

N. Andesite

O. Dacite

P. Rhyolite

Q. Sodalitite,

Nephelinolith,

Leucitolith

R. Silexite

Figure 3: TAS discrimination diagram for volcanic rocks (Middlemost, 1994)

TABLE 1: MAJOR OXIDE COMPOSITION ( Wt \%) OF THE ROCKS DETERMINED BY XRF AND FLUORINE (PPM) ANALYSIS AT THE ACME LABORATORY, CANADA.

\begin{tabular}{|l|l|l|l|l|l|l|l|l|l|}
\hline Oxides & Rhyolite & $\begin{array}{l}\text { Porphyritic } \\
\text { Biotite } \\
\text { Granite }\end{array}$ & Pegmatite & Trachyte & Migmatite & Aplite & $\begin{array}{l}\text { Fine } \\
\text { grained } \\
\text { Biotite } \\
\text { Granite }\end{array}$ & $\begin{array}{l}\text { Riebeckite } \\
\text { Granite 1 }\end{array}$ & $\begin{array}{l}\text { Riebeck } \\
\text { ite } \\
\text { Granite } \\
2\end{array}$ \\
\hline $\mathrm{SiO}_{2}$ & 75.43 & 69.07 & 77.56 & 59.92 & 68.82 & 76.58 & nd & 74.67 & 74.78 \\
\hline $\mathrm{Al}_{2} \mathrm{O}_{3}$ & 12.36 & 13.20 & 12.32 & 13.14 & 17.34 & 13.08 & nd & 11.73 & 11.43 \\
\hline $\mathrm{Fe}_{2} \mathrm{O}_{3}$ & 2.18 & 5.97 & 0.56 & 9.24 & 0.09 & 0.62 & nd & 3.70 & 348 \\
\hline $\mathrm{CaO}$ & 0.46 & 1.64 & 0.48 & 3.77 & 0.33 & 1.64 & nd & 0.28 & 0.37 \\
\hline $\mathrm{MgO}$ & 0.24 & 0.63 & 0.07 & 0.86 & $<0.01$ & 0.10 & nd & $<0.01$ & $<0.01$ \\
\hline $\mathrm{Na}_{2} \mathrm{O}$ & 2.93 & 3.09 & 3.26 & 3.39 & 3.98 & 3.84 & nd & 3.86 & 3.92 \\
\hline $\mathrm{K}_{2} \mathrm{O}$ & 4.85 & 4.76 & 5.19 & 2.96 & 9.12 & 3.41 & nd & 4.96 & 4.91 \\
\hline $\mathrm{MnO}_{\mathrm{nO}}$ & 0.02 & 0.10 & 0.03 & 0.12 & 0.12 & 0.01 & nd & 0.09 & 0.09 \\
\hline $\mathrm{TiO}_{2}$ & 0.13 & 0.77 & 0.08 & 1.04 & 0.03 & 0.11 & nd & 0.18 & 0.19 \\
\hline $\mathrm{P}_{2} \mathrm{O}_{5}$ & 0.02 & 0.26 & $<0.01$ & 0.41 & 0.02 & $<0.01$ & nd & 0.01 & 0.01 \\
\hline $\mathrm{Cr}_{2} \mathrm{O}_{3}$ & $<0.001$ & $<0.001$ & $<0.001$ & $<0.001$ & $<0.001$ & $<0.001$ & nd & 0.143 & 0.142 \\
\hline $\mathrm{Total}^{2}$ & 99.62 & 100.77 & 100.00 & 99.19 & 100.10 & 100.01 & nd & 100.06 & 100.33 \\
\hline $\mathrm{F}(\mathrm{ppm})$ & 1,749 & 380 & 71 & 949 & 25 & 79 & 240 & 800 & 1000 \\
\hline
\end{tabular}


Table 2: Trace and rare earth elements composition for rocks in the study area

\begin{tabular}{|l|l|l|l|l|l|l|l|l|}
\hline $\begin{array}{l}\text { Trace } \\
\text { Elements }\end{array}$ & Rhyolite & $\begin{array}{l}\text { Porphyritic } \\
\text { Biotite } \\
\text { Granite }\end{array}$ & Pegmatite & Trachyte & Migmatite & Aplite & $\begin{array}{l}\text { Rebeckite } \\
\text { Granite 1 }\end{array}$ & $\begin{array}{l}\text { Rebeckite } \\
\text { Granite } 2\end{array}$ \\
\hline $\mathrm{Ba}$ & 152.0 & 1213.0 & 142.0 & 875.0 & 304.0 & 840.0 & 35 & 52 \\
\hline $\mathrm{Co}$ & 50.9 & 125.7 & 161.1 & 74.8 & 92.9 & 136.0 & 5.7 & 5.4 \\
\hline $\mathrm{Cs}$ & 1.6 & 2.5 & 0.9 & 0.4 & 2.3 & 5.7 & 0.5 & 0.8 \\
\hline $\mathrm{Nb}$ & 127.1 & 30.9 & 4.3 & 55.2 & 1.3 & 5.8 & 237.2 & 159.6 \\
\hline $\mathrm{Rb}$ & 272.0 & 172.5 & 159.5 & 73.5 & 365.3 & 102.4 & 171.6 & 150.0 \\
\hline $\mathrm{Sr}$ & 38.8 & 200.2 & 64.6 & 261.5 & 106.9 & 487.8 & 11.3 & 14.3 \\
\hline $\mathrm{Th}$ & 23.2 & 6.0 & 19.9 & 9.2 & 2.2 & 11.7 & 40.2 & 18.6 \\
\hline $\mathrm{U}$ & 6.5 & 6.7 & 2.0 & 1.6 & 0.3 & 1.5 & 7.3 & 4.0 \\
\hline $\mathrm{V}$ & $<8$ & 19.0 & $<8.0$ & 9.0 & $<8.0$ & 9.0 & $<8$ & $<8$ \\
\hline $\mathrm{Zr}$ & 301.6 & 670.7 & 54.8 & 651.7 & 16.7 & 54.1 & 1017.5 & 883.9 \\
\hline $\mathrm{Y}$ & 110.6 & 41.7 & 1.6 & 57.6 & 4.2 & 8.8 & 154.1 & 106.6 \\
\hline $\mathrm{Cu}$ & 9.6 & 9.2 & 5.7 & 2.6 & 0.4 & 1.9 & 22.3 & 22.6 \\
\hline $\mathrm{Pb}$ & 15.2 & 10.8 & 14.9 & 7.2 & 5.0 & 6.6 & 3.3 & 9.3 \\
\hline $\mathrm{Zn}$ & 739.0 & 132 & 14.0 & 160.0 & 3.0 & 11.0 & 169 & 424 \\
\hline $\mathrm{Ni}$ & 0.5 & 1.9 & 2.3 & $<0.1$ & 0.4 & 0.7 & 269.9 & 308.7 \\
\hline $\mathrm{La}$ & 62.5 & 52.4 & 11.3 & 73.5 & 11.9 & 6.8 & 115.2 & 108.5 \\
\hline $\mathrm{Ce}$ & 129.3 & 115.4 & 21.7 & 146.3 & 14.8 & 15.3 & 246.2 & 218.1 \\
\hline $\mathrm{Pr}$ & 16.3 & 16.26 & 1.25 & 18.71 & 1.52 & 2.27 & 28.09 & 26.74 \\
\hline $\mathrm{Nd}$ & 63.1 & 70.4 & 3.4 & 75.8 & 4.4 & 10.5 & 103.2 & 101.0 \\
\hline $\mathrm{Sm}$ & 17.20 & 14.86 & 0.45 & 15.06 & 0.85 & 2.83 & 24.27 & 22.03 \\
\hline $\mathrm{Eu}$ & 0.41 & 2.61 & 0.10 & 4.16 & 0.50 & 0.65 & 0.70 & 0.92 \\
\hline $\mathrm{Gd}$ & 17.83 & 12.21 & 0.37 & 14.59 & 0.51 & 2.32 & 25.03 & 21.87 \\
\hline $\mathrm{Tb}$ & 3.25 & 1.59 & 0.05 & 2.13 & 0.09 & 0.36 & 4.61 & 3.54 \\
\hline $\mathrm{Dy}$ & 20.48 & 8.92 & 0.31 & 12.16 & 0.61 & 1.69 & 30.54 & 21.18 \\
\hline $\mathrm{Ho}$ & 4.01 & 1.57 & 0.04 & 2.21 & 0.08 & 0.31 & 5.83 & 3.88 \\
\hline $\mathrm{Er}$ & 11.68 & 4.15 & 0.13 & 5.63 & 0.39 & 0.89 & 16.70 & 10.56 \\
\hline $\mathrm{Tm}$ & 1.71 & 0.58 & 0.03 & 0.83 & 0.07 & 0.12 & 2.43 & 1.51 \\
\hline $\mathrm{Yb}$ & 10.24 & 3.50 & 0.18 & 4.96 & 0.47 & 0.71 & 14.50 & 9.52 \\
\hline $\mathrm{Lu}$ & 1.38 & 0.53 & 0.03 & 0.73 & 0.06 & 0.12 & 2.06 & 1.37 \\
\hline & & & & & & & & \\
\hline
\end{tabular}

\section{Physico-chemical composition of the waters in langtang area}

Table 3 shows the mean minimum and maximum values of the parameters in the waters of Langtang area. Temperature of the waters ranges from $26-27.90^{\circ} \mathrm{C}$ with a mean of $27.90^{\circ} \mathrm{C}$ as against the $26.5^{\circ} \mathrm{C}$ obtained in Crystalline Hydrogeological Province of Nigeria according to Schoeneich and Lawal, 2004. Hydrogen exponent ranges from $6.40-10.70$ with a mean of 7.32, indicating waters in the study area to be slightly acidic to mildly alkaline. Total Dissolved Solids ranges from 51.81 - 784.05 with a mean of 268.27. Reasons for this high values cannot easily be explained, but probably it may be the result of residential pollution. Total Hardness ranges from 11.09 - 407.06 with a mean 120.11. According to Davies and Deweist, 1967, classification of water hardness, $22 \%$ of the water is classified as soft, $61 \%$ as moderately hard and the remaining $17 \%$ as hard. Calcium ranges from 5.91 $117.10 \mathrm{mg} / \mathrm{l}$ with a mean of $30.31 \mathrm{mg} / \mathrm{l}$. This mean value is ten times more than the mean of $3.0 \mathrm{mg} / \mathrm{l}$ given by Schoeneich and Lawal, 2004 for calcium in Crystalline Hydrogeological Province of Nigeria. Dissolution of calcium bearing mineral alone cannot account for this high concentration of calcium in the Langtang waters. Magnesium ranges from $1.17-36.48 \mathrm{mg} / \mathrm{l}$ with a mean of $11.16 \mathrm{mg} / \mathrm{l}$, Sodium ranges from $5.07-40.37$ with a mean of $19.98 \mathrm{mg} / \mathrm{l}$. Potassium ranges from $0.59-$ 33.74 with a mean of 4.00 . These values are all higher than those given by Schoeneich and Lawal, 2004 for waters in the Crystalline Hydrogeological Province of Nigeria. Bicaarbonate in the waters ranges from $20.00-$ $672.00 \mathrm{mg} / \mathrm{l}$ with a mean of $187.97 \mathrm{mg} / \mathrm{l}$. sulphate ranges from $0.50-51.00$ with a mean of $8.10 \mathrm{mg} / \mathrm{l}$. A borehole at Bapkwai has this value of $51.00 \mathrm{mg} / \mathrm{l}$. Chloride ranges from $0.50-75.00 \mathrm{mg} / \mathrm{l}$ with a mean of 11.90. Few of the water sources have been found to have elevated level of sulphate with corresponding elevated level of nitrate. Such water sources may have been contaminated. 
Table 3: Maximum and mean values of physical and chemical parameters in Langtang area

\begin{tabular}{|l|l|l|l|l|l|l|}
\hline Parameters & No & $\begin{array}{l}\text { Minimum } \\
\text { Mg/l }\end{array}$ & $\begin{array}{l}\text { Maximum } \\
\text { Mg/l }\end{array}$ & Mean mg/l & $\begin{array}{l}\text { Crystalline } \\
\text { Hydrogeol . } \\
\text { Province } \\
\text { Average }\end{array}$ & $\begin{array}{l}\text { W.H.O } \\
\text { Standards. } \\
1984\end{array}$ \\
\hline $\begin{array}{l}\text { Temperature } \\
{ }^{C} \mathrm{C}\end{array}$ & 41 & 26.00 & 27.90 & 27.90 & $26.5^{\circ} \mathrm{C}$ & - \\
\hline $\mathrm{Ph}$ & 41 & 6.40 & 10.70 & 7.32 & $5.0-7.4$ & $6.5-8.5$ \\
\hline TDS & 36 & 51.81 & 784.05 & 268.27 & $60 \mathrm{mg} / \mathrm{l}$ & 500 \\
\hline $\mathrm{TH}$ & 36 & 11.09 & 407.06 & 120.11 & $20 \mathrm{mg} / \mathrm{l}$ & 500 \\
\hline $\mathrm{Ca}^{2+}$ & 41 & 5.91 & 117.10 & 30.31 & $3.0 \mathrm{mg} / \mathrm{l}$ & 75 \\
\hline $\mathrm{Mg}^{2+}$ & 41 & 1.17 & 36.48 & 11.16 & $1.1 \mathrm{mg} / \mathrm{l}$ & 150 \\
\hline $\mathrm{Na}^{+}$ & 41 & 5.07 & 40.37 & 19.98 & $5.0 \mathrm{mg} / \mathrm{l}$ & 200 \\
\hline $\mathrm{K}^{+}$ & 41 & 0.59 & 33.74 & 4.00 & $1.5 \mathrm{mg} / \mathrm{l}$ & - \\
\hline $\mathrm{HCO}_{3}{ }^{-}$ & 35 & 20.00 & 672.00 & 187.97 & $30 \mathrm{mg} / \mathrm{l}$ & - \\
\hline $\mathrm{Cl}^{-}$ & 36 & 0.50 & 75.00 & 11.59 & $0.6 \mathrm{mg} / \mathrm{l}$ & 500 \\
\hline $\mathrm{SO}_{4}{ }^{+}$ & 36 & 0.50 & 51.00 & 8.10 & $1.3 \mathrm{mg} / \mathrm{l}$ & 400 \\
\hline $\mathrm{F}^{-}$ & 37 & 0.12 & 10.30 & 2.47 & $0.3 \mathrm{mg} / \mathrm{l}$ & 1.5 \\
\hline
\end{tabular}

Saturation index of some mineral in Langtang area.

Saturation indices of calcite and fluorite, the two minerals which have effect on the geochemistry of fluoride in groundwater are presented in (Fig 4 ). From the figures, $77 \%$ of the water is under-saturated with respect to fluorite and $22 \%$ are close to being at equillibrum with respect to fluorite, only $1 \%$ is supersaturated with respect to the water. With respect to calcite, $57 \%$ are under-saturated, $33 \%$ are close to being at equillibrum and $10 \%$ are oversaturated with respect to calcite (Fig 5 and 6). Super-saturation with respect to calcite causes precipitation thereby removing $\mathrm{Ca}$ from the water. This makes the water more alkaline and enhances the dissolution of fluorite mineral (Handa, 1975, Gaciri and Davies, 1993). However, this is not the case in the Langtang area as the larger percentages of the water have been found to be under-saturated with respect to both minerals. Under-saturations with respect to calcite therefore have great implication on fluorite solubility the area.

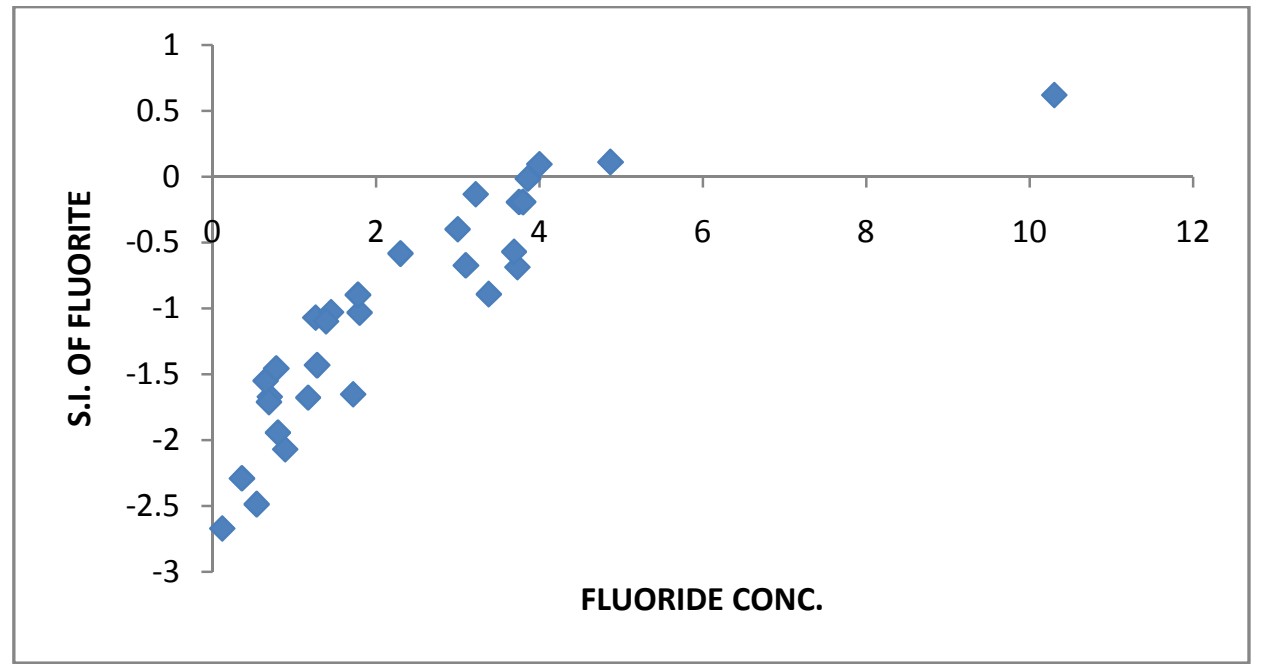

Figure 4: Saturation index of fluorite vs fluoride concentration 


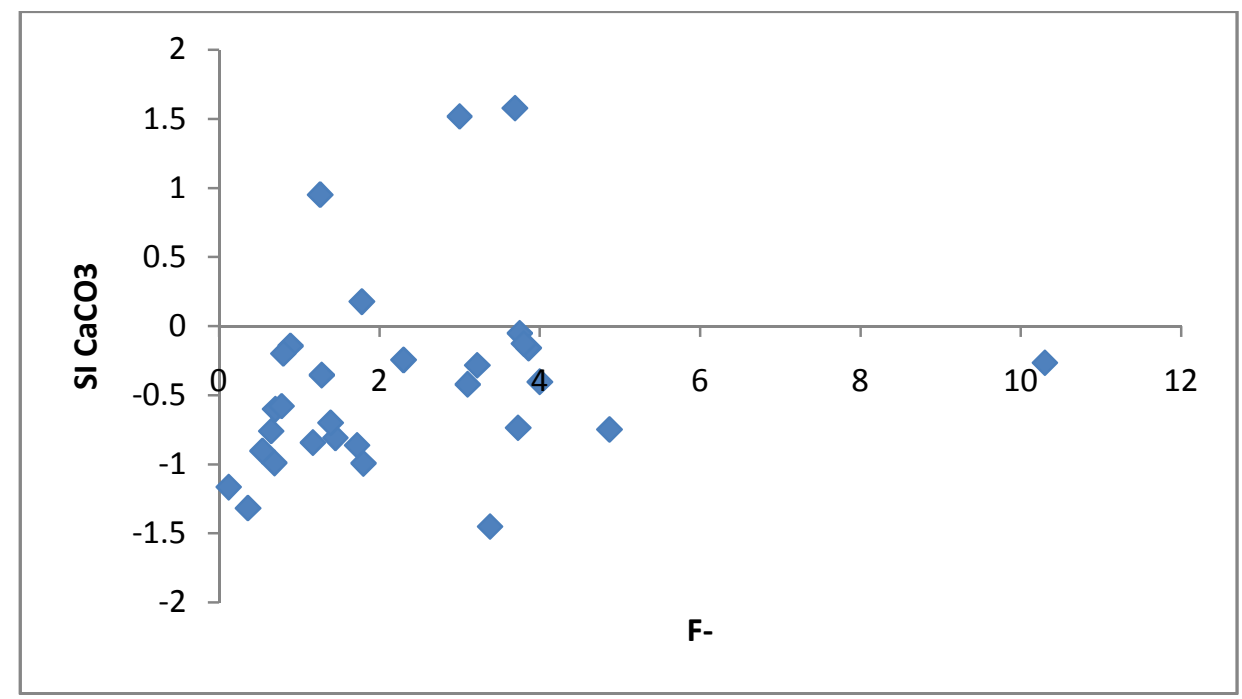

Figure 5: Saturation index of calcite vs fluoride concentration

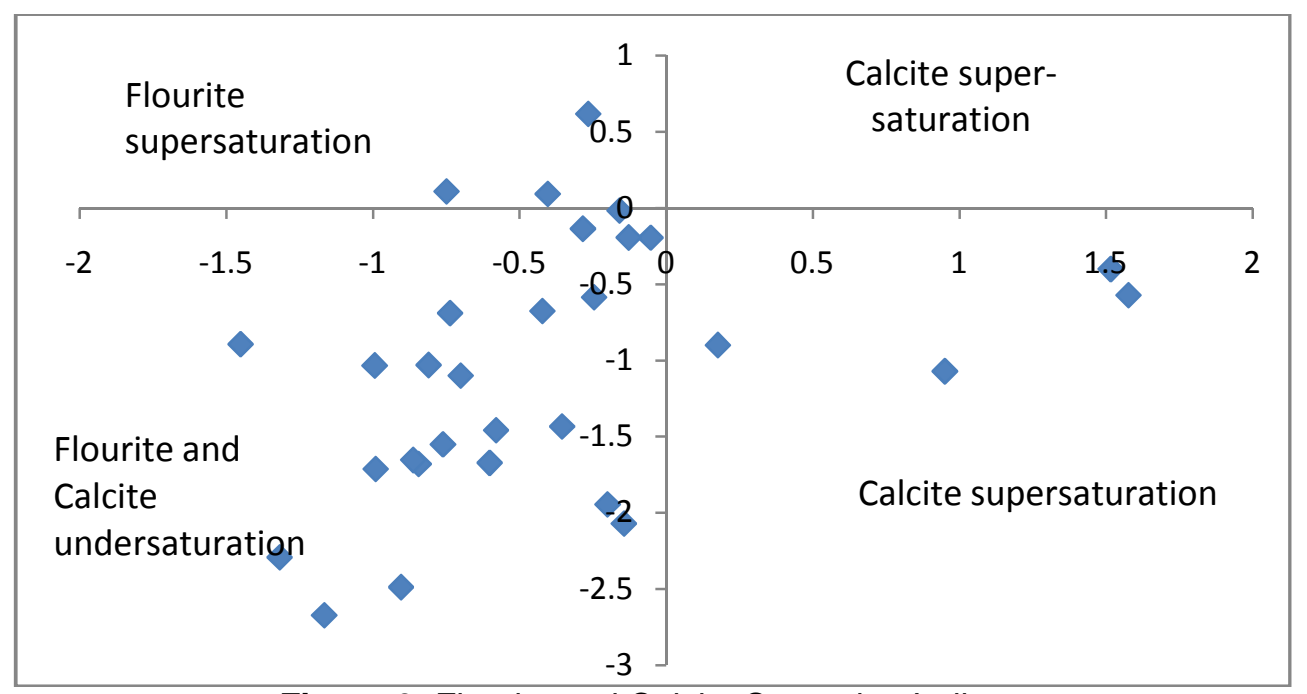

Figure 6: Fluorite and Calcite Saturation Indices

\section{Sources of fluoride in waters of Langtang area}

Fluorine occurrence in natural waters is closely related to its abundance in the local mineral rocks. Apatite and fluorite, besides the replacement of $\mathrm{OH}^{-}$by $\mathrm{F}$ in mica, hornblende and soil consisting of clay minerals (Robinson and Edington, 1946; Hem, 1991) is the major contributor of fluorine in groundwater. Anthropogenic inputs from industries and the use of phosphate fertilizers in commercial agricultural farming activities are other sources where fluoride can be released into groundwater (Rao et al., 2002). In the Langtang area, source of the fluoride is dominantly from the rock (rhyolite) with minor contribution from the other rocks. This rock type (rhyolite) has the highest level of fluorine content of 1,470 ppm. The fluorine mineral (fluorite) however, does not seem to be part of the original magma from which the rhyolite was formed, but probably a result of injection from metasomatic fluid and or derived from a melted host rock. The negative Eu anomaly in this rock indicates the removal of Eu from early crystallization of plagioclase feldspar mineral. However, the enrichment of the incompatible elements (Rb, $\mathrm{Cs}, \mathrm{Ba}, \mathrm{Pb}, \mathrm{Nb}, \mathrm{Y}, \mathrm{Tl}$ and the LREE) do not justify a fluorine mineral formed from well differentiated magma. The association of fluorine mineral to carbonate veinlets, dolomite and pyrites as revealed from the thin section studies further supports the formation of fluorine mineral from metasomatic fluid rich in carbondioxide and sulphur. The formation of the fluorine mineral may probably be the result of the ion by ion replacement in minerals (Zharikov, 2006) (replacement of an iron/magnesium mineral which probably may be a horndblende or biotite by fluorite). The fluorine is leached into the groundwater from weathering of fluorite mineral (Fig 7). The association of fluoride and calcium in the waters indicate that fluoride is leached into the waters from the dissolution of the fluorite and probably little contribution from the chlorite and the serecite minerals in the rhyolite rocks under the influence of $\mathrm{pH}$ (Krainove et al, 1969). 


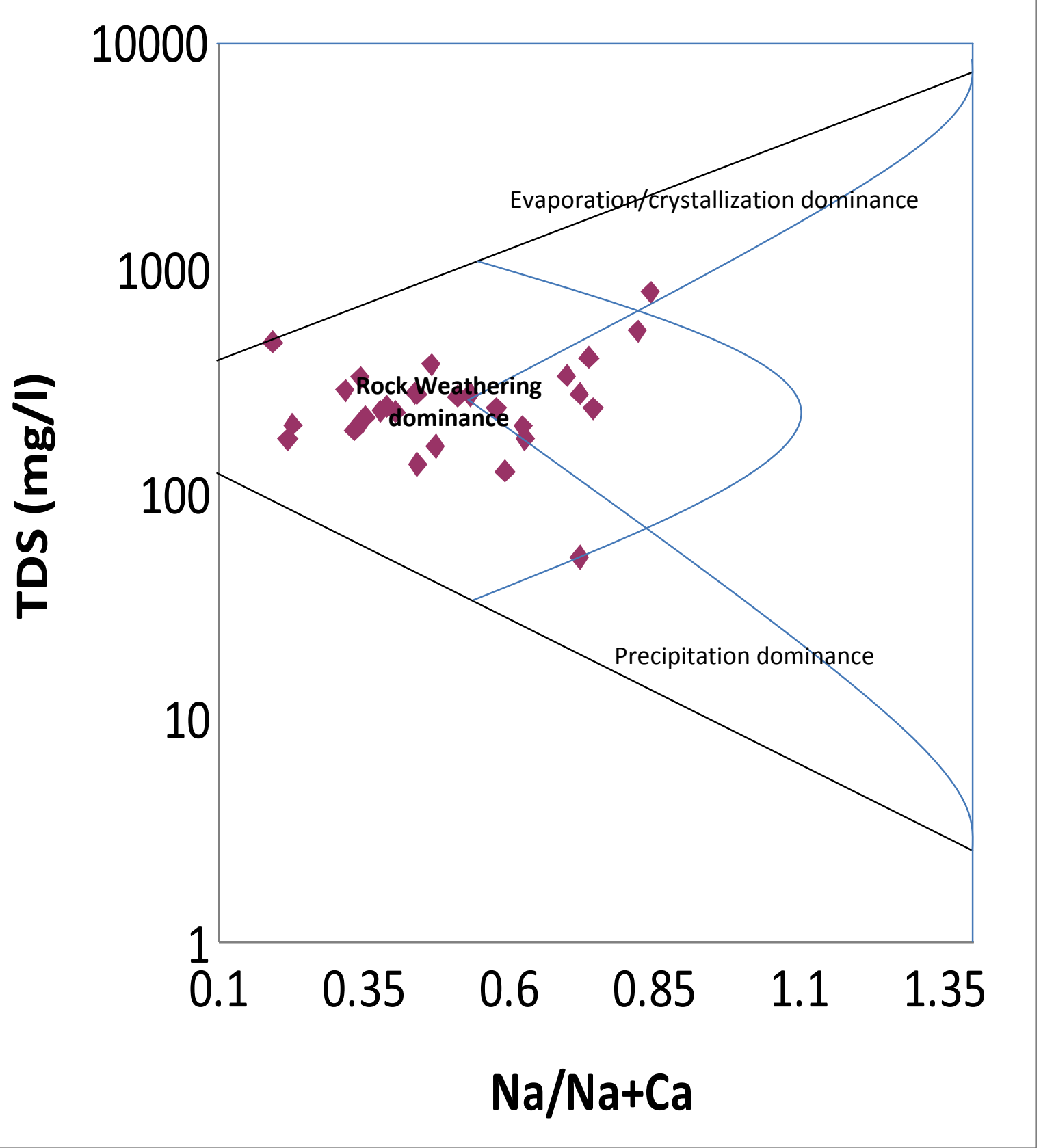

Figure 7: Gibbs diagram showing the predominant source of variation in the hydrochemistry of groundwater in the study

\section{Distribution of fluoride in Langtang waters}

Fluoride distribution symbol map of Langtang area is shown in (Fig 8). The intervals used for mapping fluoride concentrations are based on expected dose - response health outcomes given by the World Health Organisation. Fluoride concentrations higher than the WHO upper limit of $1.5 \mathrm{mg} / \mathrm{l}$ occupy a larger portion of the map (Fig 9). Fluoride concentration lower than these values, are found occupying a small portion in the northwest and some portion in the central and eastern sections of the map. No clear variation of fluoride concentration is seen in the different sources from which water was collected. Waters collected from scooped sands along stream channels have lower fluoride concentration as against those in hand dug wells and boreholes. Probably this is because waters in the streams are recently infiltrated water from immediate past rainfall and therefore did not have enough time to interact with fluorine bearing minerals. Concentration of fluoride in hand dug wells and in boreholes are similar, indicating that depth of water sources in the Lantang area do no determine the concentration of fluoride. One of the water source (hand dug well at Kuyin) located in the western portion of the study area has the highest level of fluoride concentration of $10 \mathrm{mg} / \mathrm{l}$. Groundwater flow direction plotted for the area ( Dibal, 2012) also shows that, distribution of fluoride is not controlled by direction of groundwater flow as it is evidently seen in the concentration of fluoride in some parts of the central and the south eastern portion of the map located along the direction of groundwater flow. Probably the several intruded dykes of pegmatite and apalites in the host rock and clays which may hinder groundwater flow may be responsible for variations of fluoride distribution in the area. The flow direction of the groundwater shows how little or near absence of the contribution of the riebeckite 
granite to concentration of fluoride in the study area despite their high level of fluorine content. Contribution of fluoride from these into the groundwater may therefore be towards the southern areas.

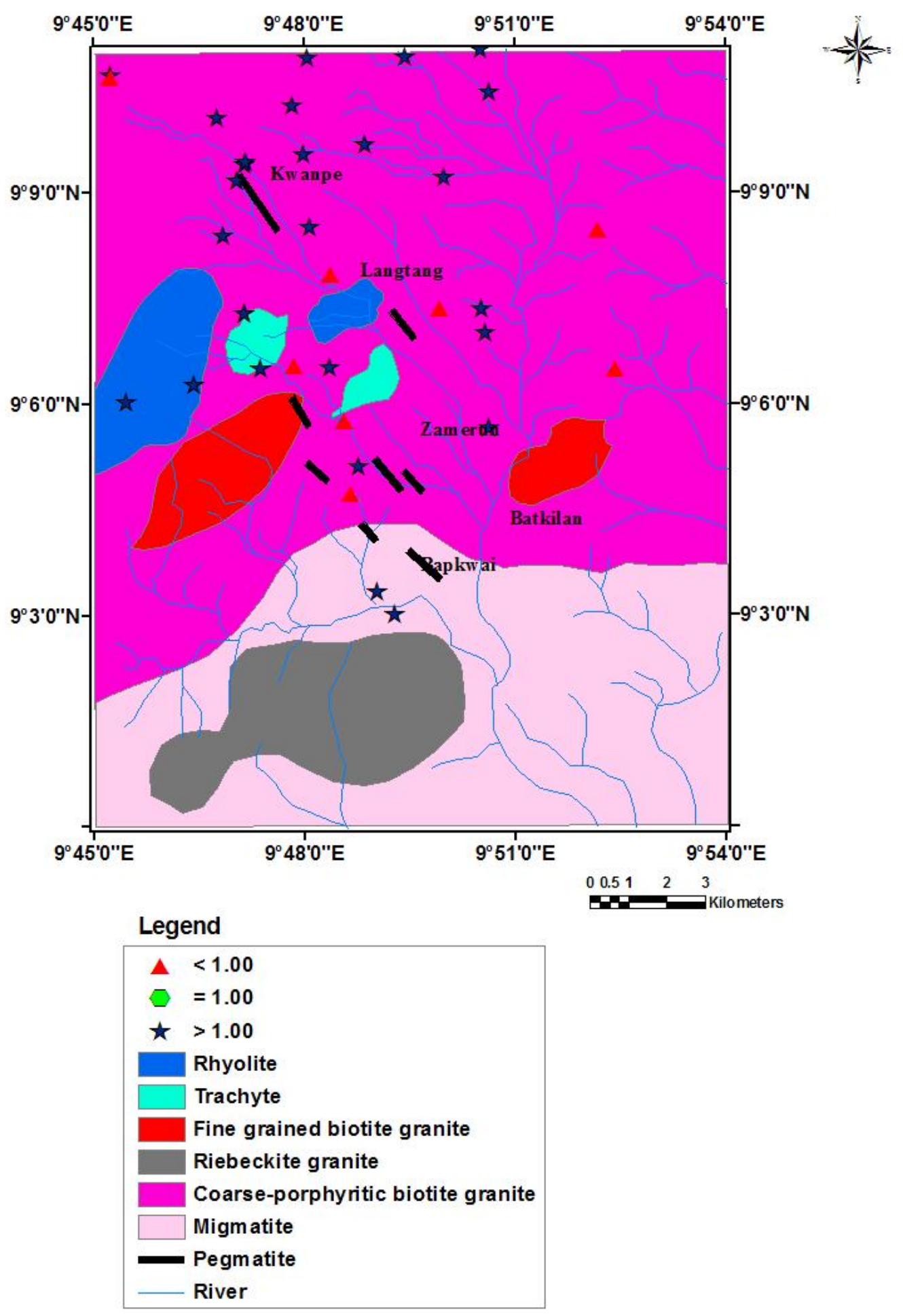

Figure 8: Concentration of fluoride symbol map of Langtang area

Fluoride and groundwater type in Langtang.

In Langtang, two major water types have been identified (Fig.9); Ca-Mg- $\mathrm{HCO}_{3}$ constituting $68 \%$ with fluoride concentration ranging from $0.12-10.30 \mathrm{mg} / \mathrm{l}$; the. $\mathrm{Na}-$
$\mathrm{HCO}_{3}$ water type constitute $17 \%$ with fluoride content in the range of $0.54-3.73 \mathrm{mg} / \mathrm{l}$ and the $\mathrm{Ca}-\mathrm{Mg}-\mathrm{SO}_{4} 3 \%$ with fluoride content of $0.80 \mathrm{mg} / \mathrm{l}$. 
Piper Diagram
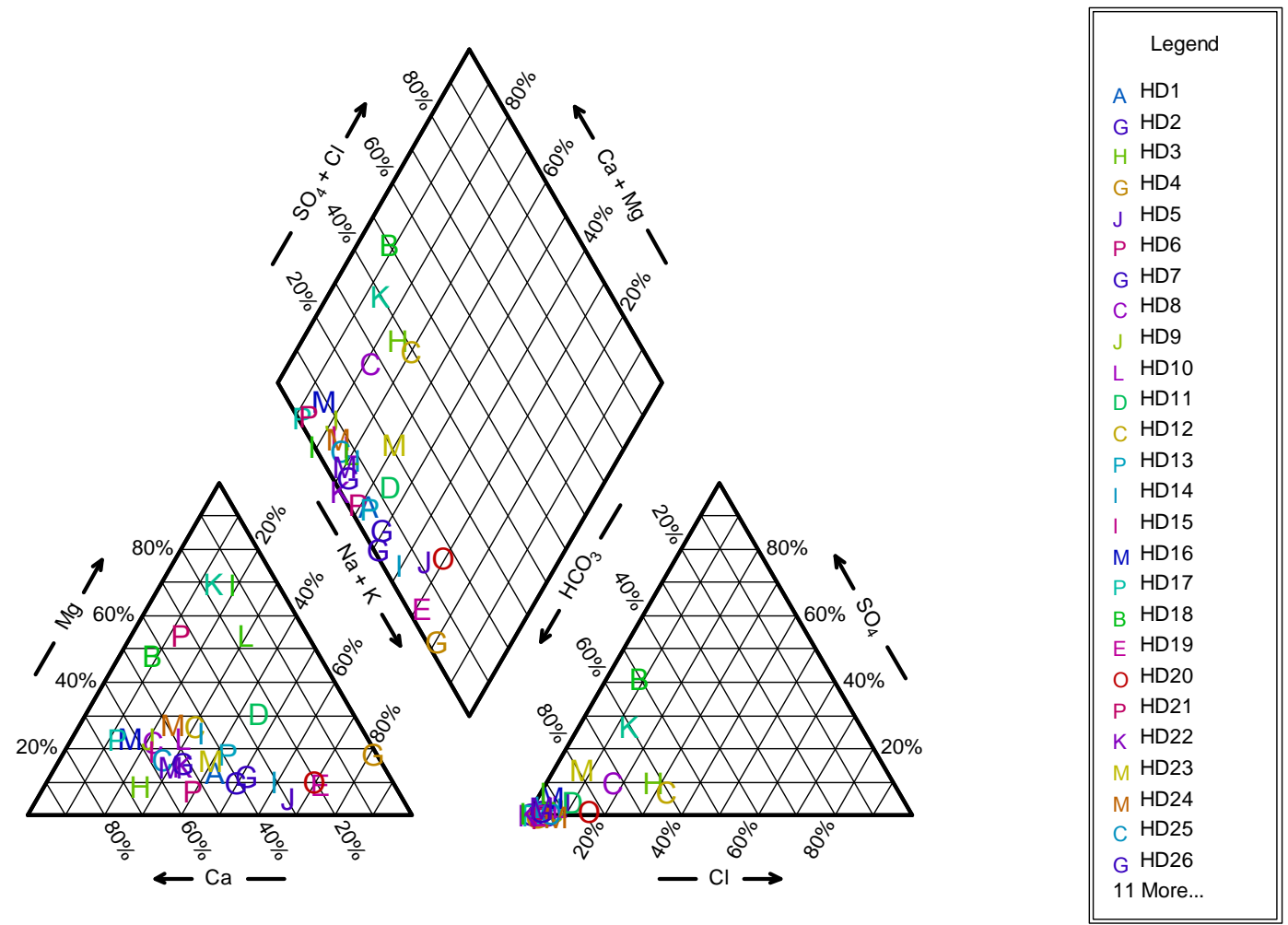

Figure 9: Piper Trillinear diagram showing water types in Langtang area

It can be seen from the figure that the waters are evolving from the $\mathrm{Ca}-\mathrm{HCO}_{3}$ to the $\mathrm{Na}-\mathrm{HCO}_{3}$ water type. However, the present study in the Langtang area differs slightly with other studies which gave the association of high fluoride groundwater to the $\mathrm{Na}-\mathrm{HCO}_{3}$ water type (Handa, 1975; Edmunds and Walton, 1983, Gaciri and Davies, 1993). The two major groundwater types obtained from the area have good relationship with content of fluoride. With over $60 \%$ of the waters in the area under-saturated with respect to both calcite and fluorite, it means that both minerals are still dissolving and going the forward direction. It is obvious that base exchange is not taking place in the area (Fig 10 ) and hence the reason for the persistence of calcium in the water. This is however, of great importance in the Langtang water, because calcium in the waters is suppressing fluorite from dissolving which could have caused more fluoride to be leached into the water leading to elevated level of fluoride in the water.

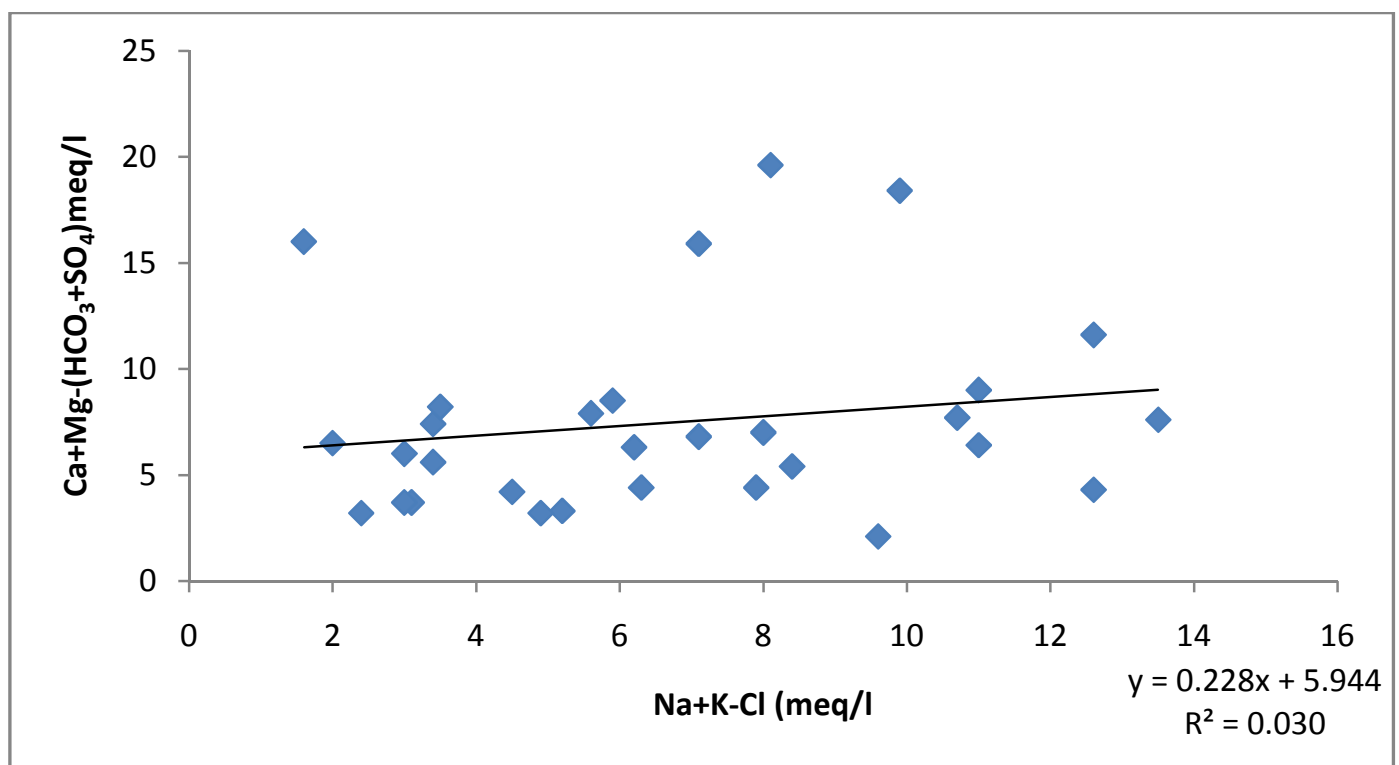

Figure 10: A plot suggesting the possibility of cation exchange in Langtang area 
Water quality and health effects of fluoride in Langtang area

In the Langtang area only $13(36 \%)$ out of the 36 ( Fig 11) water sources analysed for fluoride content imbibe waters having fluoride within the WHO 2004 optimal level of $0.5-1.5 \mathrm{mg} / \mathrm{l}$. $12 \%$ of the water sources have fluoride concentration lower than the 0.5 mg/l lower limit recommended for dental caries prevention. Population of inhabitants consuming water from these sources may therefore be at the risk of having dental caries. $52 \%$ of the water sources in the area have fluoride concentration greater than the 1.5 $\mathrm{mg} / \mathrm{WHO} \quad$ upper limit.

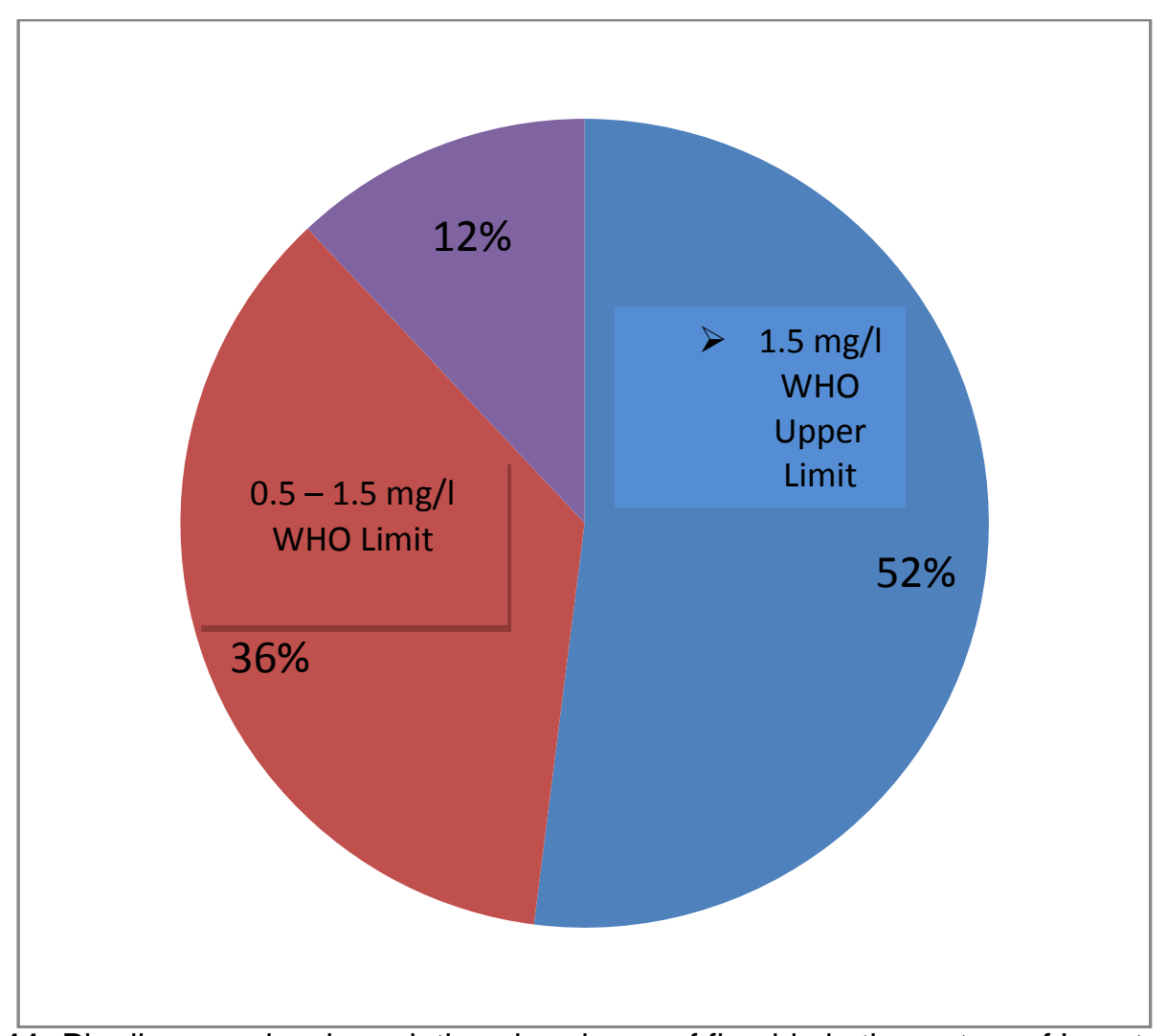

Figure 11: Pie diagram showing relative abundance of fluoride in the waters of Langtang area

Based on the WHO 2004 classification of chronic health effects of fluoride consumption in drinking water, population consuming water from 18 of the 30 water sources with fluoride value greater than $1.5 \mathrm{mg} / \mathrm{l}$ may have dental fluorosis. Inhabitants consuming water in the remaining 7 water sources with fluoride concentration from $4.0 \mathrm{mg} / \mathrm{l}$ and upwards may have chronic skeletal fluorosis. Demographic studies carried out earlier in the area (Wongdem et al, 2002) on sampled population by age group $(n=473)$ has established highest frequency of mottling $28.6 \%$ of the population aged 10 - 19 years (Table 4) with a uniform decrease towards the age group $70-79$ years. There is however, no discrimination found between these age groups with respect to sex (Table 5). This study has also established cases of genu valgum (bowing of legs) in the lower ages of between $6-9$ years (Wongdem et al in 2002). 
Table 4: Demography of the sample population by age groups $(n=473)$

\begin{tabular}{|l|l|l|l|}
\hline Age group & Frequency & Percentage (\%) & Cummulative (\%) \\
\hline $0-9$ & 93 & 19.6 & 19.6 \\
\hline $10-19$ & 136 & 28.6 & 48.6 \\
\hline $20-29$ & 95 & 20.0 & 68.2 \\
\hline $30-39$ & 62 & 13.1 & 81.3 \\
\hline $40-49$ & 44 & 9.3 & 90.5 \\
\hline $50-59$ & 26 & 5.5 & 96 \\
\hline $60-69$ & 14 & 2.9 & 98.9 \\
\hline $70-79$ & 5 & 1.1 & 100 \\
\hline Total & 475 & 100 & \\
\hline
\end{tabular}

Source: Wongdem et al, 2002.

Chronic manifestation of dental fluorosis in school children (Dibal et al, 2007) with greater manifestation in school children aged between $7-11$ years has also been established.

Table 5: Demography of sample population by age group and sex.

\begin{tabular}{|l|l|l|l|}
\hline Age group & Male & Female & Total \\
& & & \\
\hline $0-9$ & 42 & 51 & 93 \\
\hline $10-19$ & 67 & 69 & 136 \\
\hline $20-29$ & 41 & 54 & 95 \\
\hline $30-39$ & 31 & 31 & 62 \\
\hline $40-49$ & 16 & 28 & 44 \\
\hline $50-59$ & 11 & 15 & 26 \\
\hline $60-69$ & 10 & 4 & 14 \\
\hline $70-79$ & 4 & 1 & 5 \\
\hline Total & 222 & 253 & 475 \\
\hline
\end{tabular}

Source: Wongdem et al, 2002

\section{CONCLUSION}

Study on the geochemical appraisal of fluoride in the waters of langtang area show that, among the rocks of the study area, the rhyolites have the highest content of fluorine followed by the riebeckite granites and trachyte respectively $(1,470,1000,800$ and 900 $\mathrm{ppm}$ ). Fluorine crystallized in the late stage of magma crystallization, as a replacement of $\mathrm{Fe} / \mathrm{Mg}$ mineral which may probably be hornblende or biotite. The major source of fluoride in the Langtang groundwater is from the mineral fluorite hosted in the rhyolite which occurs as dykes in several places in the porphyritic hornblende - biotite granites and the migmatite gneiss.

Although the riebeckite granites have high fluorine content their contribution to groundwater is towards the southern areas due to the direction of groundwater flow in the area. No clear variation in fluoride contents exist in the different sources. Groundwater barriers such as dykes may probably be responsible for sources which have low fluoride.

Under-saturation with respect to both calcite and fluorite in the area suggest that reaction is still going on in the forward direction for both minerals. Also undersaturation with respect to calcite and lack of base exchange in the area may also be responsible for the persistence of calcium in some of the water being $\mathrm{Ca}$ $\mathrm{Mg}-\mathrm{HCO}_{3}$ type. .Groundwater evolution from $\mathrm{Ca}-\mathrm{Mg}$ $\mathrm{HCO}_{3}$ towards $\mathrm{Na}-\mathrm{HCO}_{3}$ water type results in the water being slightly alkaline and hence dissolves fluorite in the water. Inhabitants of Langtang area show manifestation of dental fluorosis in form of dental fluorosis in the age 
groups 10 - 19 years and decreases uniformly towards the older ages and bowing of legs (Genu Valgum) in lower age groups 7 - 9 years manifest bowing of legs.

\section{REFERENCES}

Ball, J. W and Nordstrom, D. K., 2004. User Manual for WATEQ4F, with revised thermodynamic data base and test cases for calculating speciation of major, trace and redox elements in natural waters. U.S. Geological Survey Open - File Report $91-183$.

Bethke, C. M., 2002. The Geochemist Workbench release 4.0. A user's guide to Rxn. In: Sahai, N and Schoonen, A.A.M (Eds) Medical mineralogy and Geocheomistry. Geochemical Society and Mineralogy, 64, $59-109$.

Burt, R. A., 1993. Groundwater chemical evolution and diagenetic processes in the upper Floridan aquifer, southern South Carolina and north eastern Georgia. United State Geological Survey Water Supply Paper 2392

Dibal, H. U and Lar, U. A., 2005. Preliminary survey of fluoride concentrations in the groundwaters of Kaltungo Town and Environs. Gombe State. Northeastren Nigeria: Water quality and health implications. Journal of Environmental Sciences, 9, (2):

Dibal, H. U., Lekmang, I. C and Lar, U. A., 2008. Dental fluorosis from Drinking water consumption in Langtang Town, Plateau State. Continental Journal of Earth sciences, 3, 77-82.

Dibal, H. U., Schoeniech, K., Lar, U. A and Garba, I., 2014. Preliminary investigation of fluoride concentration in the groundwater of Dzuma area and environs. International Journal of Environmental and Public Health. In Press

Dibal, H. U., Schoeniech, K., Lar, U. A., Garba, I and Bala, E. A., 2014. Low fluoride level in surface and groundwater in the Cretaceous Awe Formation around Keana area. In preparation.

Dissanayake. C. B., 1991. The Fluoride problem in ground waters of Sri Lanka.Environmental Problems and Health. International Journal and Environmental Studies 19, 195.

Edmunds, W. M and Walton, N., 1983. The Lincolnshire Limestone - Hydrogeochemical Evolution over a Ten Year Period. In: W.M. Edmunds and P.L. Smedley (Eds) Fluoride in Natural Waters In: $O$. Selinus et al (Eds) Essential of Medical Geology, Springer Essential of Medical Geology, Springer. $311-336$.

Gaciri, S. J and Davies, T. C., 1993. The occurrence and geochemistry of fluoride in some natural waters of Kenya. Journal of Hydrology 143, 395-412.
Handa, B. K., 1975. Geochemistry and genesis of fluoride containing ground waters in India. Groundwater 25: 255-64.

Hem, J. D., 1985. Study and Interpretation of the Chemical Characteristics of Natural Water, United State Geological Survey Water Supply Paper 2254, 263.

Hem, J. D., 1991. Study and Interpretation of the Chemical Characteristics of Natural Water. Book 2254, third edition, Scientific Publication, Jodhpur, India.

Krainove, S. R., Merkov, A. N., Petrova, N. G., Baturinskaya, I. V and Zharikova, V. M., 1969. Highly alkaline $(\mathrm{pH} \mathrm{12)}$ fluosilicate waters in the deeper zone of the Lovozero Massif. Geochem International. (6): 635-640.

Langmuir, D., 1971. The geochemistry of carbonate groundwater in central Penssylvania. In: Sahai, $\mathrm{N}$ and Schoonen (Ed) Medical mineralogy and Geochemistry. Geochemical Society and Mineralogy, 64, 59 - 109 .

Parkhaust, D. L and Apello, C. A. J., 1999. A user guide to PHREEQC (Version 2). In: Sahai, $N$ and Schoonen (Ed) Medical mineralogy and Geocheomistry. Geochemical Society and Mineralogy, 64, 59 - 109.

Richard, J. R., Martin, A. A. S and Atonio, L., 2006. Metal speciation and its role in bioaccessibility and bioavailability. In: Sahai, $\mathrm{N}$ and Schoonen (Ed) Medical mineralogy and Geocheomistry. Geochemical Society and Mineralogy, 64, 59 109.

Rao, A. S. M., Rajayalakshimi, K., Sastry, K. P. K., Rao, P. S., Rao, V. V. K and Rao, K. N., 1974. Incidence of fluoride in drinking water resources in Andhra Pradesh. Proceedings of a Symposium on Fluorosis. Hydrabad India. In: Edmunds W.M and Smedley, P.L (Ed) Fluoride in Natural Waters, Essential of Medical Geology, Springer. $311-336$.

Schoeneich, K and Garba, M. L., 2004. Geol 405 Hydrogeology. Lecture Notes for Students of Geology Department of Geology, Ahmadu Bello University, Zaria.

Smedley, P. L., Nicoli, H. B., Macdonalds, D. M. J., Barros, A. J and Tullio. J. O., 2004. Hydrogeochenistry of Arsenic and other Inorganic Constituents in Groundwaters from La Pampa Argentina. In: Edmunds W.M and Smedley, P.L (Ed) Fluoride in Natural Waters, Essential of Medical Geology, Springer. $311-336$.

WHO., 2004. Guidelines for drinking Water quality $3^{\text {rd }}$ edition, W orld Health Organization, Geneva.

Wongdem, J. G., Aderinokun, G. A., Sridhar, M. R and Selkur. S., 2002. Prevalence and Distribution pattern of 
enamel fluorosis in Langtang Town. African Journal of Medical Science. Fluoride 35. 120135.

Zharikov, V. A., Pertsev, N. N., Rusinov, V. I., Calgari, E and Fettes, D. J., 2006. Metasomatism and Metasomatic rocks. Recommendations by the IUGS Subcommission on the Systematics of Metamorphic Rocks. Web Version 01.02.07. 